in order to establish academic clinical investigation units which could operate with the necessary facilities and trained assistance, evaluating all firms' drugs in an unbiased manner. At present it seems to be sheer good luck if a firm happens to find a first-class investigator who is prepared to undertake a clinical trial, or a second-class one who will seek advice and heed it.

\section{Effects of Anaesthetics on the Circulation}

Edited by H. L. Price and P. J. Cohen. Pp. xii +293 illustrated. Springfield, Illinois: Charles C. Thomas. 1964. $\$ 10.50$.

It would be hard to imagine a better review than this of current trends of thought with regard to the applied physiology of the circulation from the anaesthetist's point of view. Indeed, the title is too modest, for here is no mere recital of the actions of one drug after another, but rather an informed account of the research which is enabling us to understand the circulation of normal man and the effects of diverse influences upon it. Each chapter is written by an expert, the subject matter being presented in three parts: circulatory regulation by the central nervous system; cardiac rhythm, contractility and output; regional blood flow and vascular reactivity, including chapters on tissue circulation, cerebral circulation, myocardial perfusion, splanchnic and renal circulation, pulmonary circulation and extremity blood flow. The presentation is always lucid, but in places a fair amount of concentration is required of the reader.

Throughout the book, emphasis is placed on clinical investigation and methods of study applicable to man. This is right and proper, for the true fascination and the true challenge of modern anaesthesia is its provision of unparallelled opportunities for physiological investigation without discomfort or harm to the patient. It is a great tribute to the editors that this book so constantly brings to mind the vivid interplay which can and should exist between "pure" physiology, pharmacology and clinical investigation and the great contributions which each can make to the others.

The volume is an "edited but complete" report of a conference sponsored jointly by the National Research Council of the United States and the New York Academy of Medicine, held in Washington in May, 1963. The contributors were drawn from the United States, Great Britain and Scandinavia. The valuable discussion sections include pertinent comments from Henry L. Price himself, whose notable research experience and editorial percipience must have gone a long way towards making a success of the whole venture.

\section{The Biliary System}

Edited by W. TAYlor. A Symposium of the NATO Advance Studies Institute. Pn. Xxv + 712 illustrated. Oxford: Blackwells. 1965. f6 15s.

This book is made up of the lectures. communications and discussions of the N.A.T.O. Advanced Study Institute Symnosium held at Newcastle-upon-Tyne in September, 1963. The contributors include anatomists. phvsiologists, biochemists, physicians, surgeons and radiologists from Britin. Eurone and the U.S.A. Accounts of recent research on the Liver and Biliary
System are presented under eight headings-1. Structural and Functional Relationships of the Liver, Biliary System and Hepatic-Lymphatic System. 2 . Metabolism and Function of Bile Salts and Acids. 3. Bilirubin metabolism. 4. Gall-bladder Function and Control of Bile Secretion. 5. Excretion of Hormones and Antibiotics in Bile. 6. Mechanisms of Bile Secretion. 7. Bromosulphthalein Tests of Bile Func tion. 8. Clinical Aspects. There are 700 pages, over 800 references and an excellent index. Much detail is included, for example, there is a superb chapter of 25 pages on the comparative anatomy of the Sphincter of Oddi.

The book is beautifully produced and very well illustrated. Probably few individuals will want to purchase a work embracing so many disciplines, but for medical and other scientific libraries it will be an extremely valuable work of reference.

\section{Neurologic Manifestations of General Diseases}

JoHN A. AITA. Pp. xiii + 921. Springfield, Illinois: Charles C. Thomas. 1964. \$24.50.

This massive compendium of neurological phenomena sets out their manifestations in general medical and surgical conditions At the end of each chapter is an extensive bibliography. This painstaking effort should be in libraries as a source of reference primarily for those whose special interests are other than reurology. Thus the cardiologist faced with a bizarre neurological problem in a patient with congenital or acquired heart disease can quite quickly refresh his knowledge by glancing at the first chapter. There is something, likewise, for the haematolo gist, allergist, gastroenterologist, radiotherapist, dermatologist and endocrinologist.

\section{Microscopic Pathology}

By S. E. Gould, D. L. Hinerman, J. G. BatSAKIS and $P$. R. BEAMER. Pp. viii +604 , illustrated. Edinburgh and London: E. \& S. Livingstone. 1965. £9.

This is a black and white atlas of some 1,200 photomicrographs of a variety of pathological conditions. There is a brief annotation to each, with two or three references. It is a handsome and well produced book. Most of the photographs are good, some, particularly of the intestinal parasites, are very good indeed. It is probably inevitable that in a large collection of photographs there will be some of indifferent quality and a few are so crowded with detail and of such low magnification as to be virtually useless. The compilers might have been better advised to choose a different format which would allow varying size of illustrations rather than to have confined themselves to an arrangement which is too often wasteful of space.

The selection of material seems curiously arbitrary: ihere are no pathological lesions of the ear illustrated and only two of the eye. Some common conditions are inadequately dealt with whilst some rare ones are included. It is difficult to justify this imbalance when we read the declared aims of this volume in the authors: preface. Here they state that the book is designed for "students of pathology and residents in all fields of medicine" to be read with standard text books. This is, of course, an American book and as there are, in the United States, pathological texts which have no illustrations, American students using 